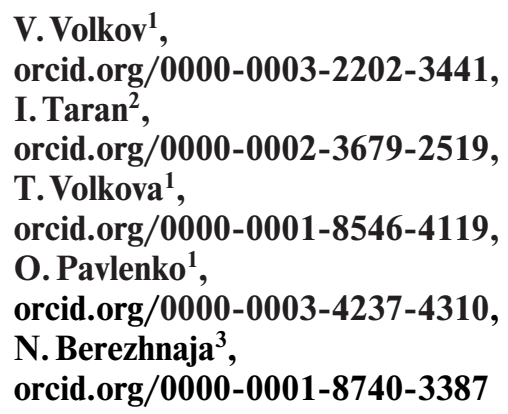

1 - Kharkiv National Automobile and Highway University, Kharkiv, Ukraine, e-mail: volf-949@ukr.net 2 - Dnipro University of Technology, Dnipro, Ukraine 3 - Kharkiv Petro Vasylenko National Technical University of Agriculture, Kharkiv, Ukraine

\title{
DETERMINING THE EFFICIENT MANAGEMENT SYSTEM FOR A SPECIALIZED TRANSPORT ENTERPRISE
}

Purpose. To identify the efficient management system for a specialized transport enterprise in terms of the varied demand owing to the parameter optimization and cost reduction.

Methodology. An approach to identify management system of the specialized transport enterprise has been proposed relying upon the system analysis principles and upon the apparatus of queuing theory. Construction of the regression models involved formalization of expenditures connected with order servicing, while a level of the parameter system effect on the estimated figure was determined using regression analysis.

Findings. Analysis of the theoretical evidence has shown that despite the numerous developed approaches intended to improve management systems for enterprises of different branches, which propose modern methods and models, it is required to develop absolutely cost-effective and adaptive procedure to determine the efficient management system for a specialized transport enterprise. An approach determining such an efficient management system exemplified by a business unit of Illich Iron \& Steel Works PJSC (Mariupol) has been proposed. Its implementation anticipates two levels: in terms of service parameters, and in terms of expenditures connected with order service of the enterprise. For the purpose, a mathematical model of such an order service system has been developed. The model takes into consideration various probability factors (i.e. ordering moments, service period, and others). Moreover, service costs have been formalized to identify optimum conditions. Values of the latter and influence parameters have been applied to develop regression models in the power form with a nonzero coefficient. The models will help identify online optimum service conditions and make managerial decisions concerning variation of the number of repair crews, vehicles, and so on.

Originality. For the first time, the paper proposes an approach as for the determination of the efficient management system for a specialized transport enterprise based upon a queuing theory taking into consideration a system analysis in the interaction between production enterprises and transport ones. Moreover, forecast models are developed concerning expenditures connected with order service of mining and metallurgical companies depending upon the number of crews, service time variations and the order quantities.

Practical value. The approach is the theoretical background to improve interaction between the specialized transport enterprises, and mining and metallurgical companies. The models may be used to develop efficient management system relying upon determination of ratio number of repair crews and vehicles at a motor transport enterprise; in turn, that will help to reduce expenditures connected with the resource use.

Keywords: management system, specialized transport enterprise, queuing theory, costs

Introduction. Service of the primary production of mining and metallurgical enterprises needs the development of the effective system for activities of the specialized transport enterprises granting transport facilities as for delivery of repair crews with equipment, repairing means, and spare parts. The abovementioned involves rapid response and fast arrival to a client. Functional complexity of the system, its high dynamics and probabilistic nature of its processes need a scientific approach to solve the problems of efficient operation.

Early in the year of 2013, Ukrainian mining and metallurgical complex involved almost 800 large and small enterprises and organizations, including 19 large smelting integrated works and plants; 12 pipe factories; more than 20 hardware plants; and more than 100 scrap-recycling enterprises localized within four economic clusters. Efficient resource use and operative scheduling of the enterprises are of significant economic effect. Thus, it is required to solve the problems of operative planning of activities by specific vehicles as the means providing delivery of repair crews for emergency order service in terms of a specialized transport enterprise being a business unit of Illich Iron \& Steel Works PJSC (Mariupol).

(c) Volkov V., Taran I., Volkova T., Pavlenko O., Berezhnaja N., 2020
Literature review. Current state of the development of motor transport is characterized by a growing role of the specialized road vehicles since in the near future they will be preferable for transportation in the context of different branches of economy [1]. Like any other production enterprise, a carrier operator, engaged in transportation within a logistic delivery system, [2] should aspire to the increased amount of its product, and to its sales [3] to improve their own financial and economic, technological, and technical indices or to maintain their high level [4]. It is important for logistic system to organize efficient transport service for mining and metallurgical enterprises with the minimum costs and maximum implementation level of modern managerial decisions [5], IT [6], and Industry 4.0 principles [7].

Since global dynamics of the external environment of enterprises continues its growth, it becomes more and more important to maintain managerial systems for organizational flexibility [8]. The authors propose collaboration-based managerial systems [9]; systems of quality evaluation and cost minimization [10]; corporate structure systems [11]; feedback systems with uncertainty consideration [12]; forecasting systems based upon fuzzy neural model [13]; and information control systems [14]. The solutions are costly ones as for the system development and its adaptation in the context of a relevant production complex. 
Current state of the development of methods and mathematical apparata has resulted in the origination of the foundations to solve new application problems whose practical utility is evaluated with the help of a high production system in any sphere of activities inclusive of mining production and metallurgical one $[15,16]$. Probable and fuzzy values as the elements of mathematical statistics apparatus are the most popular methods [17]. They are the methods making it possible to describe stochastic nature of a service market demand as well as a system of interrelation between the system subjects. Many decisions are based upon the queuing theory being a very useful method to develop complex models with probabilistic parameters and cross ratios between certain elements of the system. The method is also very helpful to determine the optimum number of service channels with the appropriate demand levels $[18,19]$.

Purpose is to identify the efficient managerial system for specialized transport enterprises under the conditions of a variable demand while optimizing parameters and reducing costs.

\section{Objectives of the study are:}

- to develop a mathematical model of order service system for the specialized transport enterprise while performing emergency repairs at mining and metallurgical companies;

- to identify stages of solving the problem concerning the development of the efficient management system for a specialized transport enterprise;

- to formulate analytical models for expenditures connected with service orders by mining and metallurgical companies and to analyze the results.

Methods. A process of rendering services by the specialized transport enterprise should involve a desire to minimize costs at each stage involving the maximized productivity in terms of compliance with time limits and cost reduction. The study considers the specialized transport enterprise being a business unit of Illich Iron \& Steel Works PJSC (Mariupol), which provides scheduled maintenance as well as accident elimination in the production area of mining and metallurgical companies. The system of customer services is regarded in terms of the varied demand for the accident order execution. That is why operational planning of activities by the specialized vehicles and repair crews will be considered from the viewpoint of a random order inflow. According to a procedure of order execution, applications inflow randomly; thus, their execution time is a random value (Fig. 1).

It is proposed to evaluate the system functioning with the help of two levels: in terms of service parameters $(K)$ and expenditures connected with the enterprise order service $\left(C_{r}\right)$.

First, we consider level one of the order service system. The level involves the parameters in terms of which the system functioning is evaluated: ability of the system to execute each of the orders; likelihood that all repair crews will participate in new order execution; likelihood that during working hours the crews will not be able to execute the order; likelihood that expectation period before the repair start will exceed average

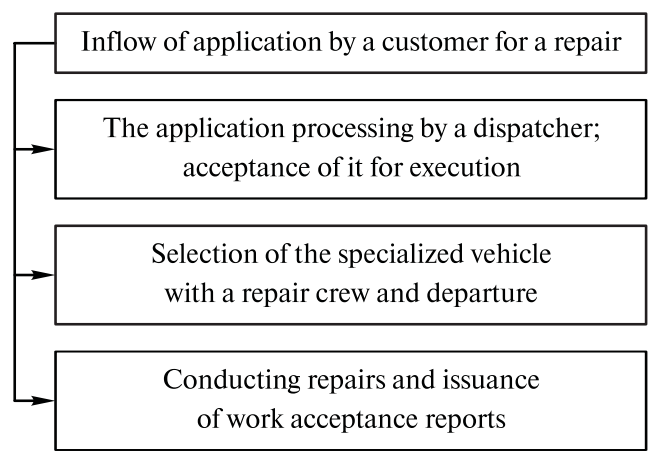

Fig. 1. Procedure of order service at an enterprise time of the repair expectation; mathematical expectation of the queue length; and the number of free repair crews.

The system of order service belongs to the queuing system: a lossless system (i.e. the application will expect its service until execution); inflow of applications to the system is a random variable belonging to a simple inflow; order execution time is a random variable. In this context, the following limitations are involved [20]: the number of orders is not limited; application inflow belongs to a simple one; and unilateral indicators of the system evaluation are used.

Let us assume that the moments of application submission is a random variable; thus, inflow of the orders is a random one. Hence, the probability that accurate number $m$ of the application will be submitted during $t$ time is [20]

$$
Y_{m}^{t}=\frac{(\eta \cdot t)^{m}}{m !} \cdot e^{-\eta t},
$$

where $\eta$ is the average number of service orders per reasonable time, $\mathrm{u} / \mathrm{h} ; t$ is time, hours; $m$ is the number of orders, units.

If $m$ increases, then probability decreases rapidly in terms of $m>\eta \cdot t$ since in terms of the equation, the denominator starts undergoing its rise faster than the numerator.

Let us assume that repair time is a random value. Taking into consideration the number of crews within the service system, average time for one order execution is determined as follows

$$
\lambda=\frac{n}{\mathrm{v}},
$$

where $v$ is the number of orders which may be executed by all the crews, units; $n$ is the number of crews within the service system, units.

A distribution law parameter is identified taking into consideration the fact that the time follows the distribution law indicator

$$
\gamma=\frac{1}{\lambda}
$$

Capability of the system to execute all the orders is determined with the help of the inequation

$$
\frac{\eta}{\gamma} \geq n
$$

If the number of repair crews within the system is less than the ratio, then the queue will increase constantly. As a result, either the system balance will take place demonstrating itself as a refusal from following orders to restore or stability or its complete failure. If the number of the repair crews far exceeds the ratio (more than per a system), it can be considered as that being underloaded (i.e. its potential is not used completely).

The dependence makes it possible to define such a failure probability as well as potential probability to improve its efficiency.

The following formula determines the probability that at the moment of a new order receipt for repair or accident prevention all the crews are involved

$$
\Omega=\frac{\gamma \cdot p_{0}}{(n-1) !(n \gamma-\eta)} \cdot\left(\frac{\eta}{\gamma}\right)^{n},
$$

where $p_{0}$ is the probability that all the crews are not involved at the moment of a new order receipt. It is identified taking into consideration the additional transition parameter

$$
p_{0}=\frac{1}{\sum_{k=0}^{n} \frac{1}{k !}\left(\frac{\eta}{\gamma}\right)^{k}+\frac{\gamma}{(n-1) ! \cdot(n \gamma-\eta)} \cdot\left(\frac{\eta}{\gamma}\right)^{n}},
$$

where $k$ is the additional transition parameter. 
The probability that during a shift the crew will not be able to respond to the order obtained early is

$$
P(\beta)=\Omega \cdot e^{-\gamma \cdot t},
$$

where $\beta$ is expectation time for the service start.

The index helps to evaluate the share of orders execution of which will start after the determined period. To do that, it is required to apply a dependence determining the number of orders still expecting to be completed after the certain period has finished

$$
m(z)=P(\beta) \cdot \eta \text {. }
$$

The index helps to consider customer complaints as well as violation of contractual relationship.

Average time for repair expectation depends upon the previously determined values

$$
T=\frac{\Omega}{n \cdot \gamma-\eta} .
$$

The index describes average time for repair expectation. Depending on regulatory data, it can also be used to evaluate quality of the system functioning.

The probability that expectation time for repair start will exceed average expectation time for the repair is

$$
P(\beta>t)=\Omega \cdot e^{-\Omega} .
$$

Moreover, it is possible to identify the probability that the repair will start no longer after $T$

$$
P(\beta \leq t)=1-P(\beta>t) \text {. }
$$

Mathematical expectation of a queue length is

$$
M=\frac{p_{n} \cdot \eta}{n \cdot \gamma \cdot\left(1-\frac{\eta}{n \cdot \gamma}\right)^{2}},
$$

where $p_{n}$ is the probability that the number of orders will be less than the number of crews

$$
p_{n}=\frac{1}{n !} \cdot\left(\frac{\eta}{\gamma}\right)^{n} \cdot p_{0} .
$$

Actually, the probability demonstrates the average number of orders which will wait for execution in terms of constant laws of a random value distribution.

The average number of noninvolved crews is

$$
R=\sum_{k=0}^{n-1} \frac{n-k}{k !} \cdot\left(\frac{\eta}{\gamma}\right)^{n} \cdot p_{0} .
$$

Consideration of the determined index within the model makes it possible to assume that it is expedient to rationalize the number of crews to improve the system efficiency.

The identified approach becomes a basis to form schematic representation of stages to solve the problem concerning the development of the efficient managerial system for the specialized motor transport enterprise to service customers while performing both preventive and emergency repairs under the conditions of variable demand (Fig. 2). Stage one evaluates the

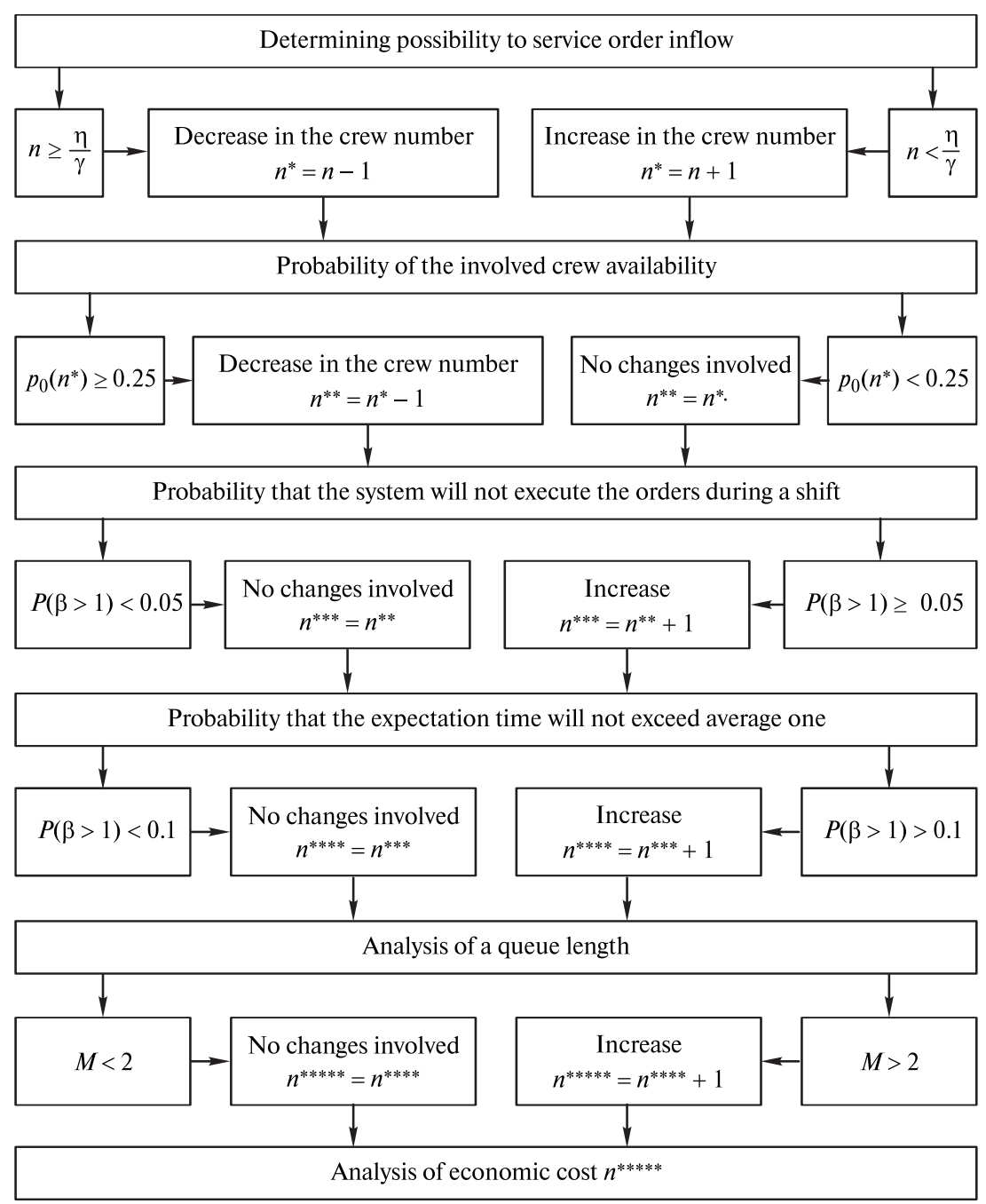

Fig. 2. Stages to solve the problem concerning the development of efficient management system for the specialized motor transport enterprise 
total probability of a long queue. If so, then the system either becomes unstable or refuses from the application.

Stage two analyzes possibilities of the crew involvement or noninvolvement at the moment when a repair order is obtained. If probability one is rather good, then there is a chance to increase the number of the crews. If probability two is rather good, then it is necessary to decrease the number of the crews. The probability that during a working day a crew will not be able to execute repair order is evaluated as follows. If the number of orders which execution improbability is great (i.e. more than $15 \%$ ), then the system should be modified. If the number is small (i.e. less than $5 \%$ ), then the system can be considered as a stable one in terms of the parameter.

Stage three analyzes average time of an order execution. Preliminary analysis of a probability for an object to be under repair during $t^{*}$ time is carried out; time for a crew delivery is recorded. Difference in the crew delivery process and maximum expectation time is responsible for a maximum index value exceeding of which is indicative of the irrationality of the developed service system. Comparison of the limited index value with its actual value makes it possible to substantiate the following improvement of the order service system. Probability of the average expectation time for execution exceed is the additional index used to supplement the previous one. It helps to analyze the order share which will not be processed during the average expectation time.

The final stage four analyzes a queue taking into consideration its length. A long queue affects very negatively the system efficiency indices. Length of the queue speaks for the necessity to improve either the system structure or the repair operation schedule. If all the indices (or some of them) do not compile with the requirements of the service system, then their improvement possibilities are analyzed. To do that, certain indices are recorded; then, the system parameters, in terms of which the indices may achieve relevant efficiency level, are determined inversely.

Hence, determination of the efficient order service system at stage one can be represented in the form of the function

$$
K=f\left(p_{0}, \Omega, P(\beta), T, P(\beta>t), P(\beta \leq t), M, P_{n}, R\right) .
$$

Let us calculate values of the function parameters for the identified conditions of the system functioning (Table 1) determined on the basis of the statistic data of the international vertically integrated group of steel and mining companies Metinvest, transportation unit of Illich Iron \& Steel Works PJSC (Mariupol).

Assume that a shift lasts 9 hours a day. Assume the number of orders and execution time as the average ones. The number
Values of influencing parameters

\begin{tabular}{|l|c|c|c|}
\hline \multirow{2}{*}{\multicolumn{1}{|c|}{ Parameter }} & \multicolumn{3}{c|}{ Level of variation } \\
\cline { 2 - 4 } & Minimum & Average & Maximum \\
\hline Number of crews, units & 2 & 3 & 4 \\
\hline One order execution, hours & 0.5 & 5.75 & 12 \\
\hline $\begin{array}{l}\text { Number of applications } \\
\text { inflowing the system, units }\end{array}$ & 1 & 2.5 & 6 \\
\hline
\end{tabular}

of crews within the service system is 4 . Determine analytical parameters of the system relying upon the obtained data (Table 2). The modeling involved the development of a program code within MS Visual Studio environment using programming language $\mathrm{C} \#$.

Resulting from the system analysis with a parameter with two crews, for instance, it is possible to conclude that the number of crews in two units will be less than the required one taking into consideration the specified input application inflow. In this context, the application flow needs a greater number of them. High probability of the fact that the crews are involved constantly and the queue is longer to compare with one-half of the orders is the specific negative feature of such a system (Fig. 3). The graph explains that if there are four crews, loss by the nonexecuted order is the least.

Then evaluate efficiency of the system functioning while determining the costs to service orders by an enterprise $\left(C_{r}\right)$ taking into consideration the expenditures connected with: repair; crew delivery to destination point and back; operation of vehicles of the specialized transport enterprise; preventive activities; and dead time of the repair crews during a work expectation period.

$$
C_{r}=\sum_{i=1}^{5} C_{i} \cdot \eta .
$$

Expenditures, connected with repairs, take into consideration the time for order execution $t_{p p}$, and the job costs $S_{p p}$

$$
C_{1}=t_{p p} \cdot S_{p p} \cdot n \cdot(1+\Omega) \text {. }
$$

Expenditures, connected with the delivery of a repair crews to the destination point and back, are determined using the delivery time $t_{d}$ and its costs $S_{d}$

$$
C_{2}=t_{d} \cdot S_{d} \cdot n .
$$

Expenditures, connected with the operation of the specialized transport enterprise vehicles, are determined as follows

Calculation results concerning functioning indices of a system for customer service

\begin{tabular}{|c|l|c|c|c|c|}
\hline \multirow{2}{*}{} & \multicolumn{1}{|c|}{ Functioning index of the service system } & \multicolumn{3}{|c|}{ The index value } \\
\cline { 3 - 6 } & & \multicolumn{2}{|c|}{$\begin{array}{c}\text { Number of crews, units } \\
\text { Boundary } \\
\text { value }\end{array}$} \\
\cline { 3 - 6 } & & 2 & 3 & 4 & - \\
\hline 2 & Probability that all crews will be noninvolved when a new application is available & 0.14 & 0.18 & 0.21 & - \\
\hline 3 & Probability that all crews will be involved when a new application is available & 0.84 & 0.20 & 0.08 & $<0.25$ \\
\hline 4 & Average time of the repair expectation, hours & 0.11 & 0.03 & 0.002 & $<0.05$ \\
\hline 5 & Probability that actual expectation period of the order execution will exceed the average one & 0.36 & 0.16 & 0.04 & $<0.20$ \\
\hline 6 & Probability that the execution will start no later than in a day & 0.64 & 0.84 & 0.98 & - \\
\hline 7 & Probability that the number of orders will be less than the number of crews & 0.15 & 0.10 & 0.03 & - \\
\hline 8 & Mathematical expectation of a queue length, units & 1.8 & 0.2 & 0.01 & $<1$ \\
\hline 9 & Average number of the noninvolved crews, units & 0.21 & 0.74 & 0.9 & - \\
\hline
\end{tabular}


Index value

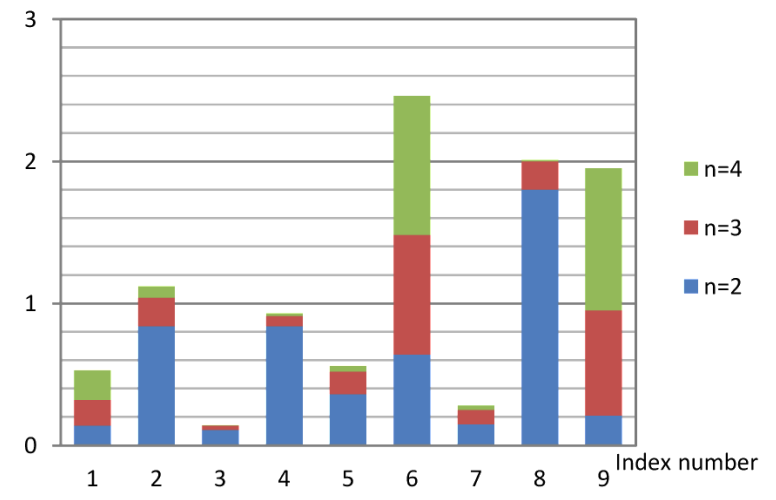

Fig. 3. Graph of the dependence of indices of service system functioning upon the number of working crews

$$
C_{3}=\left(t_{p p}+t_{d}+t_{e}\right) \cdot S_{e} \cdot a,
$$

where $t_{e}$ is the expectation time; $S_{e}$ is the operation costs of the vehicles, and $a$ is the number of automobiles.

Expenditures, connected with the preventive activities, take into consideration time, spent for them $t_{p w}$, their costs $S_{p w}$, and execution level of the total order amount $R_{\eta}$

$$
C_{4}=t_{p w} \cdot S_{p w} \cdot n \cdot R_{\eta} \cdot(1+\Omega) .
$$

Expenditures, connected with the crew dead time in the expectation of working activities, are calculated on the basis of the delay costs $S_{\text {ew }}$

$$
C_{5}=T \cdot S_{e w} \cdot n \cdot R
$$

Hence, determination of the efficient system for order service at level two can be represented in the form of the function

$$
C_{r}=f\left(t_{\Sigma}, S_{\Sigma}, R, \Omega, n, a, \eta\right),
$$

where

$$
\begin{gathered}
t_{\Sigma}=\left\{t_{p p} ; t_{d} ; t_{e} ; T ; t_{p w}\right\} ; \\
S_{\Sigma}=\left\{S_{p p} ; S_{d} ; S_{e} ; S_{p w} ; S_{e w}\right\} .
\end{gathered}
$$

The output influence parameter data was determined for the function calculation. Two parameters were selected to develop three plans of the experiments (they correspond to the number of the working crews) (Table 2): time to execute one order; and the number of orders (Table 1). Nine series of the experiments will be carried out for two parameters and three levels. The number of vehicles corresponds to the crew number value. Table 3 shows mathematical expectations of the parameter values.

Table 3

Parameter values to identify costs

\begin{tabular}{|l|c|}
\hline \multicolumn{1}{|c|}{ Parameters } & Values \\
\hline Delivery time, hours & 0.5 \\
\hline Expectation time, hours & 0.84 \\
\hline Time for the preventive activities, hours & 0.4 \\
\hline Performance level of the preventive activities & 0.3 \\
\hline Cost of the repair activities, UAH/hour & 480 \\
\hline $\begin{array}{l}\text { Cost of the working crew delivery to destination point } \\
\text { and back, UAH/hour }\end{array}$ & 180 \\
\hline Operation cost of the vehicles, UAH/hour & 280 \\
\hline Cost of the preventive activities, UAH/hour & 120 \\
\hline Cost of the repair crew dead time, UAH/hour & 170 \\
\hline
\end{tabular}

Cost, UAH

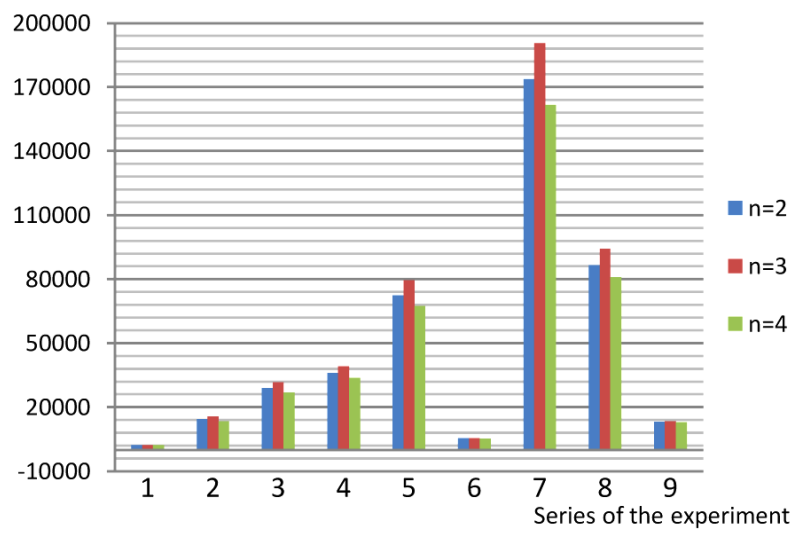

Fig. 4. Graph of the dependence of execution of orders by an enterprise upon the combination of input parameter values in terms of each experiment series

Table 4

The results of power-function regression model determination

\begin{tabular}{|c|l|}
\hline The number of repair crews, units & Regression model \\
\hline 2 & $C_{r}=e^{8.2} \cdot t_{p p}^{0.79} \cdot \eta$ \\
\hline 3 & $C_{r}=e^{8.2} \cdot t_{p p}^{0.83} \cdot \eta$ \\
\hline 4 & $C_{r}=e^{8.2} \cdot t_{p p}^{0.78} \cdot \eta$ \\
\hline
\end{tabular}

The carried-out two-factor experiment helped to determine the costs to execute enterprise orders (Fig. 4). Values of the estimated figure were calculated basing upon the determined minimum, average, and maximum influence parameter points in terms of the crew number variation from two to four. Minimum service costs were obtained when four repair crews were involved and minimum influence parameter values at the expense of expectation time savings.

Let us carry out regression analysis to analyze the effect of influence parameters on the costs [14]. The models were developed with the help of MS Excel having the embedded program to calculate linear regression and power function with nonzero coefficient. Analysis of the results helped to identify a power-form regression model with a nonzero coefficient where each index points to the degree of the relevant factor influence on the resultative factor. It has been defined that the model is the most adequate one since the values of the $R$-squared index are near-one being equal to 0.99 . Moreover, coefficient values of the regression model were also examined in terms of values of a standard error, $t$-statistics, $P$-value, low value, and high value. The models take into consideration the indices of execution time per one order and the number of the orders since they exert the influence on the result (Table 4).

The developed models are applicable to identify the projected cost values to execute orders by vehicles of mining and metallurgical companies depending upon the number of repair crews and taking into consideration certain changes in the service time and the number of orders.

Conclusions. The analysis of the developments has demonstrated that despite numerous available approaches to improve the system of enterprise managements, proposing modern methods and models, it is required to develop cost-effective and adaptive methods aimed at the identification of the efficient management system for the specialized transport enterprise. The approach considers the represented system as a multichannel queue system with expectation and lock-free queue. 
The developed mathematical model to service orders by the specialized transport enterprise exemplified by a business unit of Illich Iron \& Steel Works PJSC (Mariupol) while executing emergency repair activities at the enterprise makes it possible to involve various probability factors (i.e. moments of application inflow, service time, and others).

Certain stages concerning solving the problem to develop the efficient management system for the specialized transport enterprise have been defined. Implementation of the stages will help to make managerial decisions as for the variation in the number of repair crews, vehicles and so on. The proposed approach was applied to develop a program code within MS Visual Studio environment using programming language C\# for determination of the optimum parameters for the specialized transport enterprise management. The abovementioned helped to identify the conditions under which it is efficient to use the enterprise resources for order service.

Analytical models to define expenditures, connected with service orders by mining and metallurgical companies, have been developed. The modeling results helped to identify the values of each expenditure item as well as the parameter influence on the estimated figure in the form of a power function. In future, the regression models will make it possible to evaluate the potential of the specialized transport enterprise exemplified by a business unit of Illich Iron \& Steel Works PJSC (Mariupol) and to make operative decisions for the efficient performance of the main production units in the system of other enterprises of mining and metallurgical branch.

\section{References.}

1. Kozhevnikova, N. Yu. (2013). Specialized rolling stock as a priority growth area of a motor transport enterprise. Agrarnoe obrazovanie i nauka, (4), 10-14.

2. Naumov, V. (2017). Estimating the Vehicles' Number for Servicing a Flow of Requests on Goods Delivery. Transportation Research Procedia, 27, 412-419. https://doi.org/10.1016/j. trpro.2017.12.063.

3. Rossolov, A., Popova, N., Kopytkov, D., Rossolova, H., \& Zaporozhtseva, H. (2018). Assessing the impact of parameters for the last mile logistics system on creation of the added value of goods. Eastern-European Journal of Enterprise Technologies, 95, 70-75. https://doi.org/10.15587/1729-4061.2018.142523. 4. Vojtov, V., Berezchnaja, N., Kravcov, A., \& Volkova, T. (2018). Evaluation of the Reliability of Transport Service of Logistics Chains. International Journal of Engineering \& Technology, 7(4.3), 270-274. https://doi.org/10.14419/ijet.v7i4.3.19802. 5. Deryugin, O., \& Cheberyachko, S. (2015). Substatiation of truck selection in terms of psychophysiologic stress on a driver minimizing. Eastern-European journal of enterprise technologies, 3(75), 15-22. https://doi.org/10.15587/1729-4061.2015.42127.

6. Naumov, V. S., \& Kholeva, O. G. (2017). Forming the strategies of sustainable development of freight forwarders at transportation market. Naukovyi Visnyk Natsionalnoho Hirnychoho Universytetu, (3), 129-134.

7. Ebrahimi, M., Baboli, A., \& Rother, E. (2019.) The evolution of world class manufacturing toward Industry 4.0: A case study in the automotive industry. IFAC-PapersOnLine, 52(10), 188-194. https://doi.org/10.1016/j.ifacol.2019.10.021.

8. Kozachenko, D., Skalozub, V., Gera, B., Hermaniuk, Yu., Korobiova, R., \& Gorbova, A. (2019). A model of transit freight distribution on a railway network. Transport Problems, 14(3), 17-26. https://doi.org/10.20858/tp.2019.14.3.2.

9. Gou, J., Li, N., Lyu, T., Lyu, X., \& Zhang, Z. (2019). Barriers of knowledge transfer and mitigating strategies in collaborative management system implementations. Journal of Information and Knowledge Management Systems, 49(1), 2-20. https://doi.org/10.1108/VJIKMS-09-2018-0072.

10. Malucelli, F., \& Tresoldi, E. (2019). Delay and disruption management in local public transportation via real-time vehicle and crew re-scheduling: a case study. PUBLIC TRANSPORT, 11(1), 1-25. https://doi.org/10.1007/s12469-019-00196-y.
11. See, B. P., Yap, C. S., \& Ahmad, R. (2019). Antecedents of continued use and extended use of enterprise systems. Behaviour \& Information Technology, 38(4), 384-400. https://doi.org /10.1080/0144929X.2018.1536165.

12. Saraeian, S., Shirazi, B., \& Motameni, H. (2019). Adaptive control of criticality infrastructure in automatic closedloop supply chain considering uncertainty. International Journal of Critical Infrastructure Protection, 25, 102-124. https:// doi.org/10.1016/j.ijcip.2019.02.004.

13. Shramenko, N., Pavlenko, O., \& Muzylyov, D. (2020). Logistics Optimization of Agricultural Products Supply to the European Union Based on Modeling by Petri Nets. In: I. Karabegović (Ed.). New Technologies, Development and Application III. NT 2020. Lecture Notes in Networks and Systems, 128, (pp. 596-604). Cham: Springer. https://doi.org/0.1007/978-3-030-46817-0_69. 14. Gritsuk, I., Volkov, V., Mateichyk, V., Gutarevych, Y., Tsiuman, M., \& Goridko, N. (2017). The Evaluation of Vehicle Fuel Consumption and Harmful Emission Using the Heating System in a Driving Cycle. SAE International Journal of Fuels and Lubricants, 10(1), 236-248. https://doi.org/10.4271/2017-26-0364. 15. Sładkowski, A., Utegenova, A., Kolga, A.D., Gavrishev, S. E., Stolpovskikh, I., \& Taran, I. (2019). Improving the efficiency of using dump trucks under conditions of career at open mining works. Naukovyi Visnyk Natsionalnoho Hirnychoho Universytetu, (2), 36-42. https://doi.org/10.29202/nvn$\mathrm{gu} / 2019-2 / 8$.

16. Turpak, S. M., Taran, I. O., Fomin, O. V., \& Tretiak, O. O. (2018). Logistic technology to deliver raw material for metallurgical production. Naukovyi Visnyk Natsionalnoho Hirnychoho Universytetu, (1), 162-169. https://doi.org/10.29202/ nvngu/2018-1/3.

17. Rossolov, A., Kopytkov, D., Kush, Y., \& Zadorozhna, V. (2017). Research of effectiveness of unimodal and multimodal transportation involving land modes of transport. EasternEuropean Journal of Enterprise Technologies, 5(89), 60-69. https://doi.org/10.15587/1729-4061.2017.112356.

18. Shramenko, N., \& Muzylyov, D. (2020). Forecasting of Overloading Volumes in Transport Systems Based on the Fuzzy-Neural Model. Advances in Design, Simulation and Manufacturing II. DSMIE 2019. Lecture Notes in Mechanical Engineering, (pp. 311-320). Cham: Springer. https://doi. org/10.1007/978-3-030-22365-6 31.

19. Naumov, V., Nagornyi, I., \& Litvinova, Y. (2015). Model of multimodal transport node functioning. Archives of Transport, 36(4), 43-54.https://doi.org/10.5604/08669546.1185202. 20. Ni, D. (2015). Traffic Flow Theory. Butterworth-Heinemann. Retrieved from https://www.elsevier.com/books/traffic-flow-theory/ni/978-0-12-804134-5.

\section{Визначення ефективної системи управління спеціалізованим транспортним підприємством}

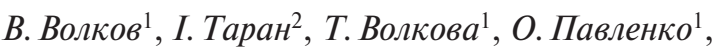 \\ Н. Бережна ${ }^{3}$
}

1 - Харківський національний автомобільно-дорожній університет, м. Харків, Україна, e-mail: volf-949@ukr.net 2 - Національній технічний університет «Дніпровська політехніка», м. Дніпро, Україна

3 - Харківський національний технічний університет сільського господарства імені Петра Василенка, м. Харків, Україна

Мета. Визначити ефективну систему управління спеціалізованим транспортним підприємством в умовах змінного попиту за рахунок оптимізації параметрів і зменшення витрат.

Методика. Використовуючи принципи системного підходу та спираючись на апарат теорії масового обслуго- 
вування, запропоновано підхід щодо визначення ефективної системи управління спеціалізованим транспортним підприємством. Для побуди регресійних моделей формалізовані витрати на обслуговування замовлень та, за допомогою регресійного аналізу, встановлено рівень впливу параметрів системи на оціночний показник.

Результати. Аналіз теоретичних розробок показав, що, не зважаючи на велику кількість розроблених підходів щодо вдосконалення систем управління підприємствами різних галузей, в яких пропонуються сучасні методи та моделі, необхідно розробити саме невитратну та адаптивну методику визначення ефективної системи управління спеціалізованим транспортним підприємством. Запропоновано підхід визначення такої системи на прикладі Приватного Акціонерного Товариства «Маріупольський металургійний комбінат імені Ілліча», на двох рівнях: за параметрами обслуговування й витратами на обслуговування замовлень підприємства. Для цього розроблена математична модель системи обслуговування замовлень, що враховує різні ймовірнісні фактори (моменти надходження замовлень, час обслуговування та інші). Також формалізовані витрати на обслуговування, за якими визначаються оптимальні умови, та на основі їх значень і параметрів впливу отримані регресійні моделі у ступеневій формі з ненульовим коефіцієнтом. Побудовані моделі дозволять в оперативному режимі визначати оптимальні умови обслуговування та приймати управлінські рішення щодо варіювання кількості ремонтних бригад, кількості автомобілів тощо.

Наукова новизна. У роботі вперше запропоновано підхід щодо визначення ефективної системи управління спеціалізованим транспортним підприємством на основі теорії масового обслуговування, з урахуванням системного підходу у взаємодії виробничих і транспортних підприємств. Також побудовані прогнозні моделі визначення витрат на обслуговування замовлень гірничо-видобувних і металургійних компаній у залежності від кількості бригад, часу обслуговування та числа замовлень.

Практична значимість. Розроблений підхід є теоретичною основою для вдосконалення взаємодії спеціалізованих транспортних підприємств і гірничодобувних та металургійних компаній. На основі отриманих моделей можна побудувати ефективну систему управління на основі визначення раціональної кількості ремонтних бригад і автомобілів на автотранспортному підприємстві, що, у свою чергу, дозволить зменшити витрати на експлуатацію ресурсів.

Ключові слова: система управління, спеціалізоване транспортне підприємство, теорія масового обслуговування, витрати

\section{Определение эффективной системы управления специализированным транспортным предприятием}

\section{В. Волков ${ }^{1}$, И. Таран ${ }^{2}$, Т. Волкова 1 , А. Павленко ${ }^{1}$, Н. Бережная ${ }^{3}$}

1 - Харьковский национальный автомобильно-дорожный университет, г. Харьков, Украина, e-mail: volf-949@ukr.net 2 - Национальный технический университет «Днепровская политехника», г. Днепр, Украина

3 - Харьковский национальный технический университет сельского хозяйства имени Петра Василенко, г. Харьков, Украина
Цель. Определить эффективную систему управления специализированным транспортным предприятием в условиях изменяющегося спроса за счет оптимизации параметров и уменьшения затрат.

Методика. Используя принципы системного подхода и опираясь на аппарат теории массового обслуживания, предложен подход к определению эффективной системы управления специализированным транспортным предприятием. Для построения регрессионных моделей формализованы затраты на обслуживание заказов и, с помощью регрессионного анализа, определен уровень влияния параметров системы на оценочный показатель.

Результаты. Анализ теоретических разработок показал, что, несмотря на большое количество разработанных подходов по совершенствованию систем управления предприятиями различных отраслей, в которых предлагаются современные методы и модели, необходимо разработать именно незатратную и адаптивную методику определения эффективной системы управления специализированным транспортным предприятием. Предложен подход определения такой системы на примере Частного Акционерного Общества «Мариупольский металлургический комбинат имени Ильича», на двух уровнях: по параметрам обслуживания и затратам на обслуживание заказов предприятия. Для этого разработана математическая модель системы обслуживания заказов, которая учитывает различные вероятностные факторы (моменты поступления заказов, время обслуживания и другие). Также формализованы затраты на обслуживание, по которым определяются оптимальные условия, и на основе их значений и параметров воздействия получены регрессионные модели в степенной форме с ненулевым коэффициентом. Построенные модели позволят в оперативном режиме определять оптимальные условия обслуживания и принимать управленческие решения при варьировании количества ремонтных бригад, количества автомобилей и др.

Научная новизна. В работе впервые предложен подход к определению эффективной системы управления специализированным транспортным предприятием на основе теории массового обслуживания, с учетом системного подхода во взаимодействии производственных и транспортных предприятий. Также построены прогнозные модели определения затрат на обслуживание заявок горнодобывающих и металлургических компаний в зависимости от количества бригад, времени обслуживания и числа заказов.

Практическая значимость. Разработанный подход является теоретической основой для совершенствования взаимодействия специализированных транспортных предприятий и горнодобывающих и металлургических компаний. Полученные модели позволят построить эффективную систему управления на основе определения рационального количества ремонтных бригад и автомобилей на автотранспортном предприятии, что, в свою очередь, уменьшит затраты на эксплуатацию ресурсов.

Ключевые слова: система управления, специализированное транспортное предприятие, теория массового обслуживания, затраты.

Recommended for publication by V.V.Slesaryev, Doctor of Technical Sciences. The manuscript was submitted 10.10.19. 